\title{
The Atmospheric Release Advisory Capability
}

\author{
Marvin H. Dickerson \\ Paul H. Gudiksen \\ Thomas J. Sullivan
}

Manuscript Date: February 1983

\author{
DISCLAIMER
}

\begin{abstract}
This repoit was prepared as an account of work sponsored by an agency of the United States Government. Neither the United States Government nor any agency thereof, nor any of their employes, makes any warranty, express or implied, or assumes any legal liability or responsibility for the accuracy, completeness, or usefulness of any information, apparatus, product, or process disclosed, or represents that its use would not infringe privately owned rights. Reference herein to any specifh commercial product, process, or service by trade name, trademark, manufacturer, or otherwise does not necessarily constitute or imply its endorsement, recommendation, or favoring by the United States Government or any agency thereof. The views and opinions of authors expressed berein do not necessarily state of reflect those of the United States Government or any agency thereof.
\end{abstract}

\section{LAWRENCE LIVERMORE LABORATORY University of California $\bullet$ Livermore, California $\bullet 94550$}




\section{Contents}

$\underline{\text { Page }}$

Abstract. ...................... 1

Introduction .................... 1

The ARAC System .................... 2

Methods of Operation ................ 3

Expansion Plans. . . . . . . . . . . . . . . . 5

Near-Term Expansion . . . . . . . . . . . . 5

Long-Term Expansion . . . . . . . . . . . . . 7

Research Activities . . . . . . . . . . . . . . . ?

Cooperative Studies with Foreigri Governments . . . . . . . 7

Reactor Containment Physies. . . . . . . . . . . . . 8

Model Development and Improvements. . . . . . . . . . . 9

Major Project Goals. . . . . . . . . . . . . . . . . . . . 9

FY $1983 \ldots \ldots \ldots \ldots$. . . . . . . . . . . . 9

FY $1984 \ldots \ldots \ldots \ldots$

FY $1985 \ldots \ldots \ldots \ldots$

Acknowledgment ................... 10

References. . . . . . . . . . . . . . . 11

Appendix A. Activities During 1980-1982 ........... 12

FY $1980 \ldots \ldots \ldots \ldots$

Alerts .................... 12

Exercises. . . . . . . . . . . . . 16

FY $1981 \ldots \ldots \ldots \ldots \ldots$

Alerts ..................... 18

Exercises........................ 21

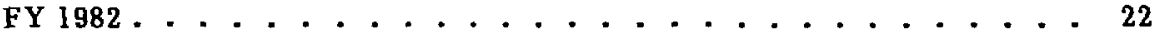

Emergencies ................... 22

Alerts . . . . . . . . . . . . . . . . . 23

Exercises. . . . . . . . . . . . . . . . 23 


\section{Abstract}

The Atmospheric Release Advisory Capability (ARAC) project is a Department of Energy (DOE) sponsored rear-time emergency response service available for use by both federal and state agencies in case of a potential or actual atmospheric release of nuclear material. The project, initiated in 1972, is currently evolving from the research and development phase to full operation. Plans are underway to expand the existing capability to continuous operation by 1984 and to establish a National ARAC center (NARAC) by 1988. This report describes the ARAC system, its utilization during the past two years, and plans for its expansion during the next five to six years. An integral part of this expansion is due to a very important and crucial effort sponsored by the Defense Nuclear Agency to extend the ARAC service to approximately 45 Department of Defense (DOD) sites throughout the continental U.S. over the next three years.

\section{Introduction}

Federal agencies are responsible for operating their nuclear facilities in a manner consistent with the protection of public health and safety. This includes the development of emergency response plans in the event a toxic substance is released accidentally from an operating facility. In 1972, the Department of Energy's (DOE's) predecessor, the Atomic Energy Commission (AEC), realized that the response to nuclear accidents could be improved substantially by developing a capability for reat-time estimation of transport and dispersion of radioactivity released into the atmosphere. It was thought that such a capability, when integrated with various radiation measurement systems, could help emergency response personnel improve their reat-time assessments of the potential consequences of an accident. That idea led to Lawrence Livermore National Laboratory's (LLNL's) development of the Atmospheric Release Advisory Capability (ARAC). 1,2. This capability uses advanced, three-dimensional atmospheric transport modeling of pollutants entrained in regional-scale flow systems and improved communications for disseminating predictions to local accident-response officials.

The objective of the ARAC project, as designed in 1973, is to provide real-time predictions of dose levels and the extent of surface contamination resulting from accidental releases of radionuclides from AEC nuclear facilities. This objective has since been expanded to include support to the DOE and DOD by assessing the consequences of potential or actual releases of radionuclides resulting from a wide spectrum of accidents such as nuclear extortion threats, nuclear weapons accidents, nuclear power piant accidents, reentry of nuclear powered satellites into the atmosphere, as well as providing the Federal Aviation Administration (FAA) with estimates of the radiation doses to passengers and crews on aircraft that may intercept a debris cloud from an atmospheric nuclear test.

During the past decade the ARAC has evolved from a research to an operational phase. It has responded to approximately 75 real-time situations, including exercises. The system is currently being expanded to include additional users, the upgrading of computational facilities, and increased staff. This expansion will permit con' inuous operation of the ARAC center in Livermore by the end of FY 1984. This report describes the system, its capabilities, and its utilization and 
future plans, as well as the interest the system has generated outside the continental U.S.

\section{The ARAC System}

The ARAC system integrates a devoted professional staff, data acquisition, data analysis, and transport and diffusion models to provide a spectrum of resources and capabilities for reartime response to an atmospheric release of radioactive material. Members of the professional staff that operate the ARAC system are trained in health physics, atmospheric sciences, electronics engineering, or computer science, and many have been associated with real-time emergency response for 10 or more years. Other professional resources are available at LLNL to help cupplement and broaden the ARAC resource base if required.

Another vital part of the ARAC system is the minicomputer/communications network used to provide real-time input data, data management, analysis and quality control, and the transmission of assessment products to the appropriate authorities concerned with accident consequences and determining countermeasures required to protect the public. This network is currently being upgraded and expanded and will be discussed further in the next section of this report.

Several computer models are available to ARAC for use in estimating the consequences of atmospheric releases of hazardous materials on local, regional, and global scales. Local (within about $10 \mathrm{~km}$ ) and regional calculations (out to about 100 $\mathrm{km}$ ) are performed with the three-dimensional numerical transport and diffusion codes, MATHEW 3 and ADPIC4, for estimating air concentrations and ground contamination from continuous or instantaneous releases from point sources. The MATHEW code uses surface and upper air winds to develop three-dimensional, massconsistent wind fields that include the effects of topography. Using these wind fields, the ADPIC code, a three-dimensional, particle-in-cell transport and diffusion cide, calculates the time-dependent dispersion of inert or radioactive pollutants. The code can include the effects of stratified shear flows, calm conditions, topography, wet and dry deposition, and radioactive decay. The ADPIC code has also been adapted to simulate fallout patterns of particulates with given particle-size distributions and the plume depletion of particulates over various terrains. To evaluate how well these models simulate pollutant transport and dispersion in the real atmosphere, the ARAC staff participated with other research groups in a series of regionalscale tracer experiments conducted in Idaho and South Carolina from 1974 to 1978. These experiments involved the release of tracers that could be detected by sensitive surface and airborne sampling systems out to a distance of 80 $\mathrm{km}$ from the release points. Comparison of the observations with the calculations indicated that the two agreed within a factor of two approximately $65 \%$ of the time and within a factor of three $80 \%$ of the time.

The current verified models for fallout and long-range transport and diffusion (KDFOC2 ${ }^{5}$ and $2 B P U F F, 6$ respectively) are used for global-scale transport and diffusion problems associated with nuclear weapons tests. These models were tested extensively from 1964 to 1970 at the Nevada Test Site.7,8 Isotopic airborne concentrations, surface air concentrations, and surface deposition patterns were, when compared with experimental data, within a factor of three at ranges up to thousands of kilometres. 


\section{Methods of Operation}

A RAC's response to an accident depends on the nature and location of the accident. Of course, it responds most rapidly to accidents occurring at those on-line sites receiving ARAC service. The permanent data bases developed for these sites include geography, topography, and the locations of meteorological measurement systems and are stored in model input format for rapid access during an emergency. In addition, data describing the nature of potential accidental releases at each site are available at the ARAC center. A schematic diagram of the center's interactions with other organizations during an emergency response is shown in Fig. 1. When notified of an emergency at one of the ARAC-serviced sites, the ARAC staff collects information about the nature of the accident directly from the site emergency response personnel. They simultaneously acquire pertinent meteorological data from the site and the surrounding region from the Air Force Global Weather Central (AFGWC) and the National Weather Service (NWS) and/or Weather Net, as well as from the site itself. Using minicomputers for data acquisition and processing, the staff views the data graphically for quality control purposes before initiating the model calculations. Likewise, they carefully screen the model results, which consist of computer-generated displays of radiation dose and surface contamination patterns overlaid on a site map, before transmitting them directly to site emergency response personnel.

A telecopier is currently used to transmit ARAC assessments to the sites however, the expansion will include the utilization of a small computer at each site to receive and display the plots on a color CRT with hardcopy capability. During normal LLNL working hours, initial estimates of the consequences of an accidental release will be available to the user within about $15 \mathrm{~min}$ after the center is notified. A more detailed analysis will be available within about $45 \mathrm{~min}$, after notification. Response times during nonworking hours are about 2 to $3 \mathrm{~h}$. These initial estimates will be updated continually as additional radiological and meteorological information from the on-scene response teams become available to the ARAC center. Interactions between personnel at the ARAC center and the site are highly dependent on local site capabilities. Thus, while some sites are almost

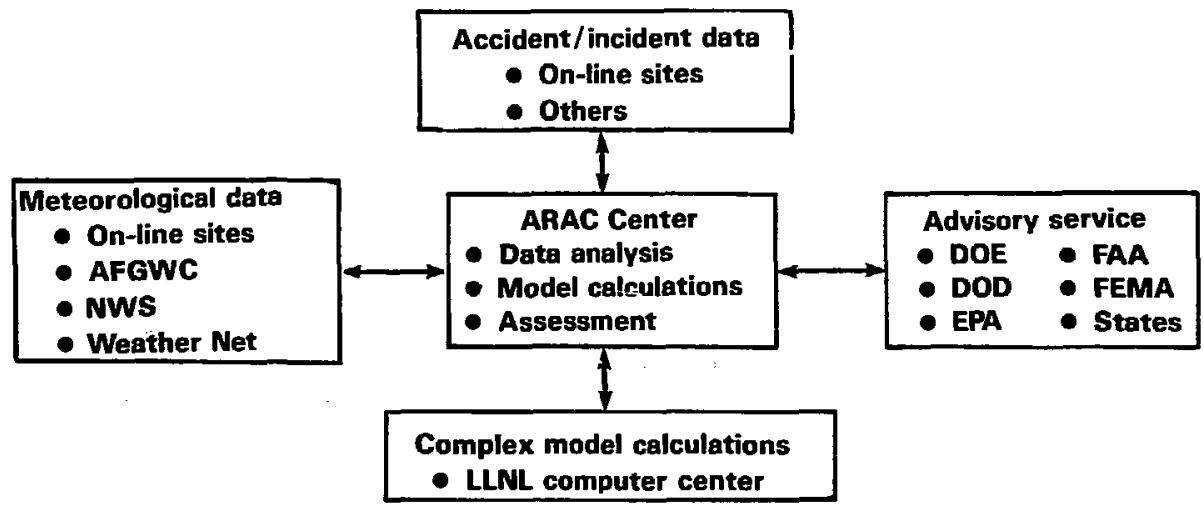

FIGURE 1. ARAC interfaces and functions. 
totally dependent on the ARAC results for impact assessments of an accidental release, other sites use regional model calculations to extend and enhance their close-in (within site boundary) assessments.

ARAC support to the DOE and the DOD at sites not regularly serviced by ARAC requires a slightly different approach. Meteorological data throughout the region of interest are obtained through the AFGWC computer link, which provides global access to surface and upper-air measurements at approximately 10,000 locations. Measurements near the accident location are obtained by telephone from local authorities (i.e., air-pollution-control agencies, emergency response teams, etc.). Topographical information for the continental U.S. is extracted from a master terrain data base which was developed from over 300 U.S. Geological Service (USGS) data tapes, while USGS maps provide both geographic and terrain data in the event of an accident outside the U.S. These data are then processed in a manner analogous to that of an ARAC-serviced site.

The ARAC has been involved in a variety of real- and nonrealtime responses during the past decade. Table 1 lists by category the events to which ARAC has responded since its inception, while Fig. 2 shows a time history of the real-time responses listed in Table 1. Detailed deseriptions of these responses are provided in Appendix A.

TABLE 1. ARAC utilization.

\begin{tabular}{|l|c|c|c|c|c|c|}
\hline \multicolumn{9}{|c|}{ Real-time } & Nonrear-time \\
\hline FY & Emergeney & Special & Alert & Exercise & Tracer & $\begin{array}{c}\text { Exercises and } \\
\text { Assessments }\end{array}$ \\
\hline 1974 & 1 & & & & 3 & \\
1975 & & & & 1 & & \\
1976 & & & 1 & 2 & 3 & \\
1977 & 1 & $1^{\mathrm{a}}$ & & 3 & & \\
1978 & 1 & $2^{\mathrm{a}, \mathrm{b}}$ & 2 & 1 & 2 & \\
1979 & 1 & & & 1 & & 9 \\
1980 & 2 & $1^{\mathrm{c}}$ & 5 & 5 & & 9 \\
1981 & & $2^{\mathrm{a}, \mathrm{d}}$ & 7 & 10 & 2 & 19 \\
1982 & 2 & & 3 & 9 & & 9 \\
\hline Total & 8 & $6^{\mathrm{f}}$ & 18 & 32 & 10 & 19 \\
\hline
\end{tabular}

a - Chinese atmospheric test

$\mathrm{b}$ - COSMOS 954 reentry

c - Purge of $85 \mathrm{Kr}$ from TMI-2 reactor

d - Israeli destruction of Iraqi reactor

e - Presidential Commission on TMI accident

$\mathrm{f}$ - does not include tens of nuclear extortion threats 


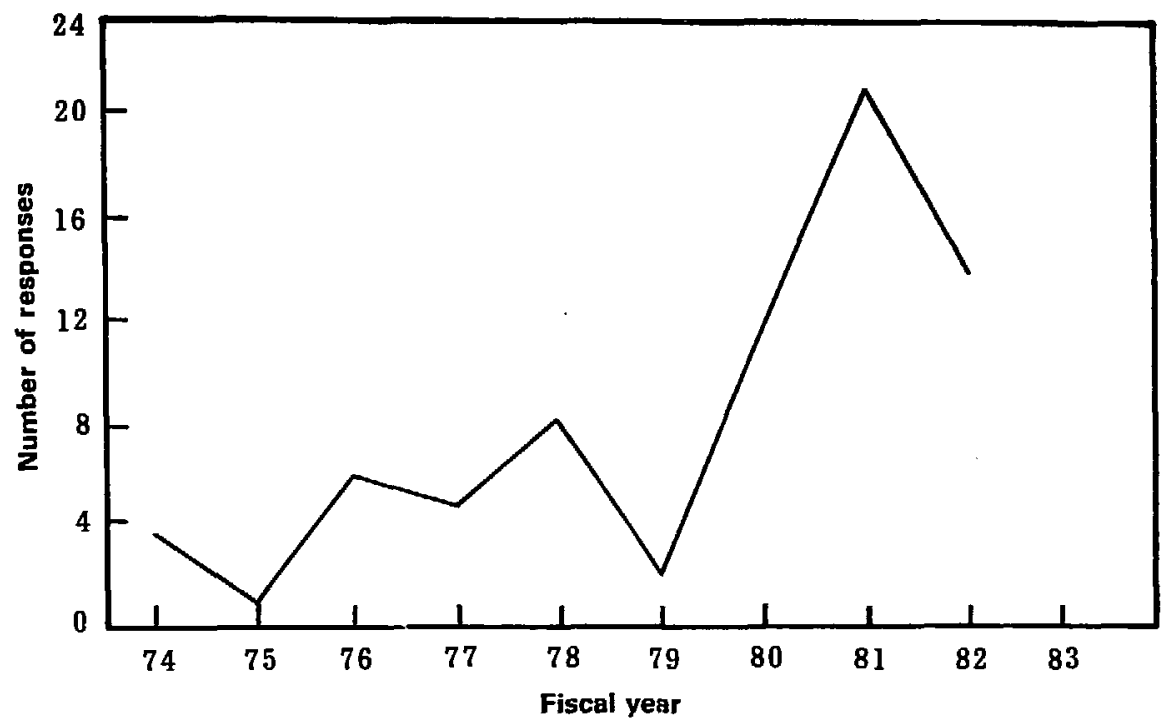

FIGURE 2. History of reat-time responses. Nuclear extortion threats are not included.

In addition to its most important function of providing both initial and followup estimates of the consequences of an accidental release, ARAC products are used:

- To provide guidance for the deployment of ground and aerial radiological measurement resources.

- To estimate the amount of material released in an accident by combining field radiological measurements with calculations.

- To screen the meteorological and radiological data for consistency.

- To advise federal agencies about the potential conseguences of an accident, (e.g., to advise the FAA air corridor safety).

- To perform detailed post accident analyses.

\section{Expansion Plans}

\section{Near-Term Expansion}

Several events since the Three Mile Island (TMI) reactor accident in 1979 have led to the in-progress expansion of the ARAC system. ARAC's role during the controlled venting of $85 \mathrm{Kr}$ from the TMI-2 reactor containment vessei in June and July 1980, was to help the Environmental Protection Agency (EPA) protect public 
health by verifying the $85 \mathrm{Kr}$ release rates and exposure rates near the reactor site. Subsequently, the ARAC service has become a federally-supported emergency response capability that can be utilized by any federal agency or state government to independently evaluate the consequences of an accidental release of toxic material into the atmosphere. On the basis of this philosophy, the ARAC service was asked to respond to the 1980 Titan II missile accident in Damascus, Arkansas. This event focused the Office of the Secretary of Defense on the possible utilization of ARAC in support of DOD-wide emergency response capability at a time when a critical review of DOD emergency preparedness was underway. After a thorough evaluation of the ARAC service, the DOD requested that the service be implemented at those fixed military facilities within the continental U.S. that have the capability to handle nuclear material (e.g., U.S. Air Force Strategic Air Command bases). This implementation was started in FY1981 and is expeeted to be complete by FY1985. Thus, about 45 DOD facilities, in addition to several DOE facilities and state offices of emergency preparedness, will be included in the ARAC service. The ARAC will also continue to provide support to the FAA in case of foreign nuclear atmospheric tests and to DOE in extortion cases involving the threatened use of nuclear material.

Considerable effort is presently underway to expand the staff, office, and computational facilities needed to meet the goals of a 24-h/day operational system. This expansion will allow the ARAC center

- To provide a staff highly trained in emergency response procedures for continuous operation.

- To rapidly respond to accidents at any of about 100 fixed sites.

- To simultaneously manage three emergency responses.

- To respond rapidly to an accident at any "nonfixed" location.

- To provide color graphics plots and expanded computational capabilities to fixed sites.

- To automate many manual data processing functions within the center.

- To complete installation of backup hardware.

The center's hardware expansion for backup redundancy was about $75 \%$ complete by the end of FY1982. This expansion consisted primarily of the acquisition of a DEC VAX 11/782 multiprocessor system. During FY1983 the current VAX 11/780 will be upgraded to an 11/782 model, and redundant DEC PDP $11 / 23$ front-end communication processors will be installed. Software is being developed for a DEC PC-350 computer, that will be installed at each DOD site to provide rapid communication with the ARAC center. This computer has a color graphics capability, enabiling rapid display of the ARAC plots at the affected site during an emergency.

This addition of new computer systems involves a major redesign of the software support system for integrated operations on a single central processor. The three distinct phases of on-going software support development arc listed below along with their expected completion dates. 
Phase I - Basic System (Spring 1983). This phase encompasses the software needed to perform such basic functions as meteorological data collection, archival, display, model input file generation, and the transmission of graphical plots to site computer systems.

Phase 1 I - Upgraded System (Fall 1983). This phase includes the sof tware needed to communicate with the new site computer systems at on-line DOD and DOE sites and the implementation of improved assessment formulation systems. These systems include an automatic preliminary model calculation, automatic product query and transmission, and the installation of such improved öata acquisition systems as digital weather facsimile, digital weather radar, etc.

Phase III - Complete System (Spring 1984). This phase will include completion of enhanced graphical displays, and of an automatic national (U.S.) geographic data base, implementation of all ARAC models on the VAX 11/782, automatic archival of a complete problem response, and automatic generation of a problem response report.

Additional facilities are required to meet the expanded ARAC activities. A $1500-\mathrm{ft}^{2}$ module was added to the ARAC center during FY1982 to house the additional computer equipment. A training facility was also added during FY 1982 to train site users, as well as to provide space for offices and conference rooms. Within the next year, additional office space will be built to house the ARAC staff as it expands to meet continuous operations during FY1984.

\section{Long-Term Expansion}

Preliminary studies have been initiated to determine the requirements for expanding the ARAC service as a national emergency response system. The N ARAC would provide emergency response service for both radioactive and chemically hazardous material releases from DOE and DOD (worldwide) facilities, as well as from nuclear power plants and chemical storage and transport accidents that could involve a state or federal response. Requirements for a permanent building to house the operational and technical staffs have been determined, and a conceptual design report (CDR) has been developed to describe these requirements. Present planning indicates that the NARAC would be operational in FY1988, assuming that budget requirements for permanent housing, computer facilities, and staff increases are met over the next several years. Once in place, the center would be the focal point for assessing hazards due to any toxic material release that involved the responsibility and/or participation of the iederal government and state governments within their own jurisdiction. Also, it is envisioned that the center would provide a broad range of training for emergency response personnel through computer simulation and ar:ess to a history of prior accidents and their consequences.

\section{Research Activities}

\section{Cooperative Studies with Foreign Governments}

In terest in the ARAC service has recently broadened to the international scale. A long-term cooperative arrangement has been instituted with Italian 
scientists within the ltalian Nuclear and Alternate Energy Commission (ENEA).9 This agreement was initiated when ENEA requested the MATHEW/ADPIC models for inclusion in the development of ARIES10,11 (Accidental Release Impact Evaluation System), a somewhat similar real-time emergency response and assessment capability in support of the ltalian nuclear power program. This arrangement includes annual exchange visits between members of LLNL and ENEA in support of a joint research program designed to enhance further development of the ARIES and ARAC systems. Since both systems are currently evolving from the research to the operational phase, the associated research efforts are being directed toward improving their present assessment capabilities. The three major areas of current interest are:

1. Further development of the MATHEW/ADPIC models by both ENEA and LLNL staff members. This includes improving the methodologies for estimating close-in doses, plume rise and building wake effects, rainout and washout, deposition, and space-variable surface roughness.

2. Further evaluation of the MATHEW/ADPIC models, using meteorological and tracer data acquired from field experiments conducted by several ltalian meteorological organizations at a coastal site north of Rome. These experiments promise to yield data that will be valuable to both LLNL and ENEA scientists, especially because the models have not been thoroughly evaluated for coastal meteorological conditions. Likewise, the A tmospheric Studies in Complex Terrain (ASCOT) 12,13 experiments conducted in California and Cclorado will provide data to both organizations that will be useful in evaluating the models in complex terrain settings.

3. Improvement in the confidence levels of the AR.AC and ARIES assessments by (1) standardizing the model input parameterizations, and (2) investigating appropriate methods for integrating the radiological measurements with the model predictions.

ln addition, the Japan Atomic Energy Research Institute has recently implemented the MATHEW/ADPIC models on their computer system for the purpose of emergency response planning purposes. Recently, the Swedish government requested that the ARAC staff cooperate with their scientists to implement the MATHEW/ADPIC codes on their computer facilities.

\section{Reactor Containment Physics}

Significant difficulties have been encountered by ARAC while using present technology to estimate realistic release rates from a malfunctioning or damaged reactor. Considerable information is emorging about the chemical and physical behavior of radionuclides in an environment equivalent to that which can exist in a reactor containment vessel under various accident conditions, however, this information has not been assembled into a realistic model to deseribe potential release rates from reactors under various conditions of excursion from normal operating conditions. We are now in the process of developing a model to estimate release rates that can account for the interaction of the containment atmosphere with the released radionuclides, for the chemical reactions of the individual radionuclides, and for the effect of high-velocity jets on the dilution of the material as it exits the 
containment area under high pressure, after a crack or hole occurs in the containment vessel.

\section{Model Development and Improvements}

In addition to research activities related to the MATHEW/ADPlC computer codes discussed above, we will be investigating the feasibility of including timedependent atmospheric boundary layer models in the ARAC service during the next several years. Our objectives are to develop capabilities to forecast meteorological variables (pril... ily wind speed, direction, and temperature), air concentration and ground deposicion on space scales of approximately $200 \mathrm{~km}$, anó time scales of 6 to 12 hours within a real-time operational framework. Initially, candiàate models will be screened to deterrine which model or models can be converted to an operational environment for emergency response forecasting of regional-scale meteorology. The final step in this process will be to interface the output from a meteorological forecast model to a transport, diffusion, and deposition model to determine air concentration and ground deposition patterns.

\section{Major Project Goals}

To complete the planned expansion of the ARAC service, the following major goak have been established for the next three years.

\section{FY 1983}

- Complete the analysis, design, and implementation of the new ARAC operating system and remote terminals.

- Expand the operating hours of the ARAC center from $8 \mathrm{~h} / \mathrm{day}, 5$ days/ week to $16 \mathrm{hrs} /$ day, 5 days/wk.

- Add about 15 DOD facilities to the service.

- Update the four DOE facilities to the new system.

- Continue to work with the states of California, New York, and Pennsylvania on emergency response planning and implementation.

- Continue to work with scientists in Italy, Japan, and Sweden on emergency response planning and improved methodologies.

\section{FY 1984}

- Complete the addition of the continental U.S. DOD facilities to the ARAC service.

- Begin installation of the computer-based site systems at DOD facilities. 
- Expand the operating hours of the ARAC center to $24 \mathrm{~h} /$ day, 7 days/week.

- Initiute the investigation of requirements associated with responses to atmospheric releases of nonnuclear hazardous materials.

- Continue cooperative work with state, federal, and foreign governments on improvements in emergeney response capabilities and procedures.

\section{FY 1985}

- Complete installation of remote terminals at DOD facilities.

- Start implementing emergeney response services for nonnuclear hazardous material.

- Begin designing of the expanded NARAC service.

- Continue cooperative work with state, federal, and foreign governments.

\section{Acknowledgment}

This work was performed by the Lawrence Livermore National Laboratory under the auspices of the U.S. Department of Energy under contract No. W-7405Eng-48 and the U.S. Defense Nuclear Agency under IACRO 83-274. 


\section{References}

1. M. H. Dickerson and R. C. Orphan, "Atmospheric Release Advisory Capabiiity," Nuclear Safety, 17, 281-289 (1976).

2. M. H. Dickerson, J. B. Knox, and R. C. Orphan, "ARAC Update-1979," Lawrenee Livermore National Laboratory, Livermore, CA, UCRL-52802 (1979).

3. C. A. Sherman, "A Mass-Consistent Model for Wind Fields Over Complex Terrain," J. Appl. Meteor., 17, 312-319 (1978).

4. F. Lange, "ADPIC-A Three-Dimensional Particle-in-Cell Model for the Dispersal of Atmospheric Pollutants and Its Comparison to Regional Tracer Studies," J. Appl. Meteor., 17, 320-329 (1978).

5. T. Serduke, Lawrence Livermore National Laboratory, private communication (1978).

6. T. V. Crawford, A Computer Program for Calculating the Atmospheric Dispersion of Large Clouds, Lawrence Livermore National Laboratory, Livermore, CA, UCRL̨-50179 (1966).

7. J. B. Knox, "Numerical Modeling of the Transport Diffusion and Deposition of Pollutants for Regions and Extended Scales," JAPCA, 24(7), 660-664 (1974). Also published in APCA Reprint Series, Air Pollution Meteorology, Air Pollution Control Association, Pittsburgh, PA, 15213, (1977).

8. J. B. Knox, M. H. Dickerson, R. Lange, and K. R. Peterson, Transnational Air Quality: The Case for the Stratosphere, Lawrence Livermore National Laboratory, Livermore, CA, UCRL-79428 (1977).

9. P. H. Gudiksen, R. Lange, M. H. Dickerson, T. J. Sullivan, L. C. Rosen, H. Walker, G. B. Boeri, R. Caraccioln, and R. Fiorenza, Joint Research and Development on Toxic Material Emergeney Response Between ENEA and LLNL: 1982 Progress Report, Lawrence Livermore National Laboratory, Li vermore, CA, UCRL-53345 (1982).

10. CNEN-DISP: ARIES - 1st Progress Report, RTI-AMB (1981).

11. CNEN-DISP: Exercitazione del Piano di Emergenza esterna per la centrale elettrcnucleare di Caorso-9 Febbraio 1982. Scenario dell'evoluzione dell'incidente, RTI-DISP(B 2).

12. M. H. Dickerson and P. H. Gudiksen, ASCOT FY-1981 Progress Report, Lawrence Livermore National Laboratory, Livermore, CA, UCID-18878-81 (ASCOT 81-2) (1981).

13. M. H. Dickerson and P. H. Gudiksen, ASCOT FY-1982 Progress Report, Lawrence Livermore National Laboratory, Livermore, CA, UCID-18878-82 (ASCOT 82-7) (1982). 


\section{Appendix A. Activities During FY 1980-1982}

FY 1980

ARAC responded to eight alerts, including the TMI (Three Mile Island) $85 \mathrm{Kr}$ purge and the LLNL earthquake, plus four comprehensive exercises. Table Al lists the events in chronological order. Only December, March, and August passed without significant ARAC involvement, affording opportunities for improving operations.

\section{Alerts}

Two of the major alerts to which ARAC responded were undertaken with no advance notice. The Savannah River Plant experienced a hydrogen sulfide accident (cracked pipe) on the morning of May 21, 1980. Because of the potential involvement of lange quantities of toxic materials, ARAC emergency support was requested. The ARAC staff was involved for 8 days: four $24-\mathrm{h}$ and four $8-\mathrm{h}$. Public highway, railroad, and river traffic was suspended for eight days until the alert was terminated without incident.

The ARAC staff initially prepared some realtime calculations of plume transport and diffusion. Then, as the situation stabilized, they made attempts to develop probable nighttime drainage flow conditions, and performed attendant plume transport calculations (Fig. Al) to anticipate the most likely exclusion zones in case the event deteriorated. Fortunately, an engineering solution was developed and implemented to resolve the problem.

The second no-notice alert was the Titan II missile accident near Damascus, Arkansas, on September 19, 1980. ARAC was called primarily because of the possible involvement of a nuclear weapon in the accident. The response to this emergency involved complete development of the essential files of topography, meteorological stations, and geography, using newly developed capabilities. A series of possible accident scenarios was calculated to bracket the potential hazard. Sample calculations shown in Figs. A2 and A3 are based on an explosive dispersal of a normalized amount of source material. Both respirable dose and surface deposition after one hour of dispersion are presented.

Another alert involved the release of $85 \mathrm{Kr}$ from the reactor containment building at TMI Unit No. 2, a consequence of the original accident in Spring 1979. ARAC support for this release was very extensive it involved numerous tests and exercises for two weeks preceding the release, deployment of two key staff personnel to Middletown, Pennsylvania, and 12 days of continuous 24- $\mathrm{h}$ /day calculational and data-collection support. ARAC's primary role was to act as a federal government operated, evaluated, and independent assessment system to provide support to both the Environmental Protection Agency (EPA) and the State of Pennsylvania during the release. ARAC calculations were used actively in the initial deployment of helicopter and mobile measurement systems. After five days of repeated confirmation between the helicopter sampling and ARAC calculations, the helicopters were released and the mobile-sampler/model calculation methodology was used exclusively for the remainder of the purge. Figures A4 and A5 depict two examples of the type of calculations prepared for the EPA during the release. A complete post-release assessment is now in progress, using the actual release-rate data and the various sampler measurements. 
TABLE Al, Summary of ARAC responses during FY 1980.

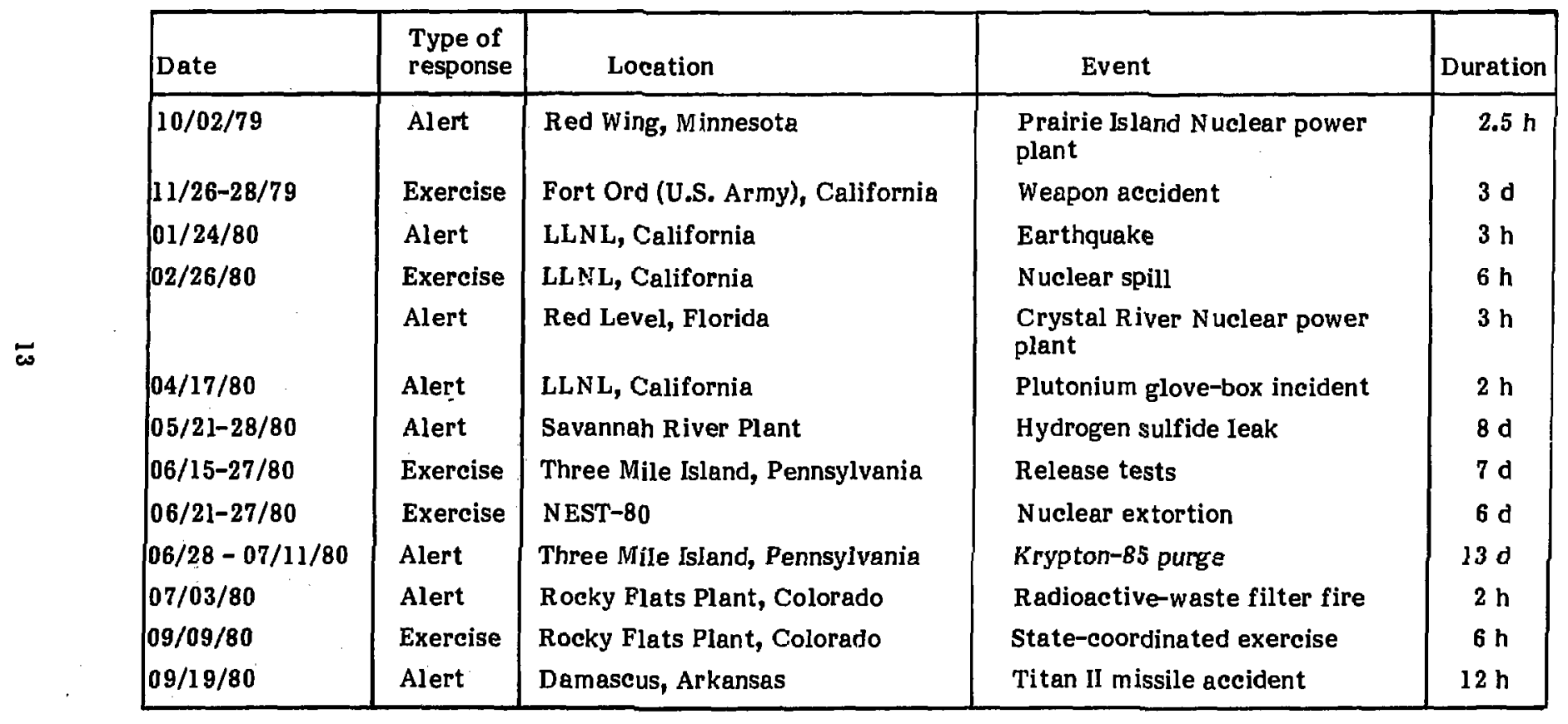




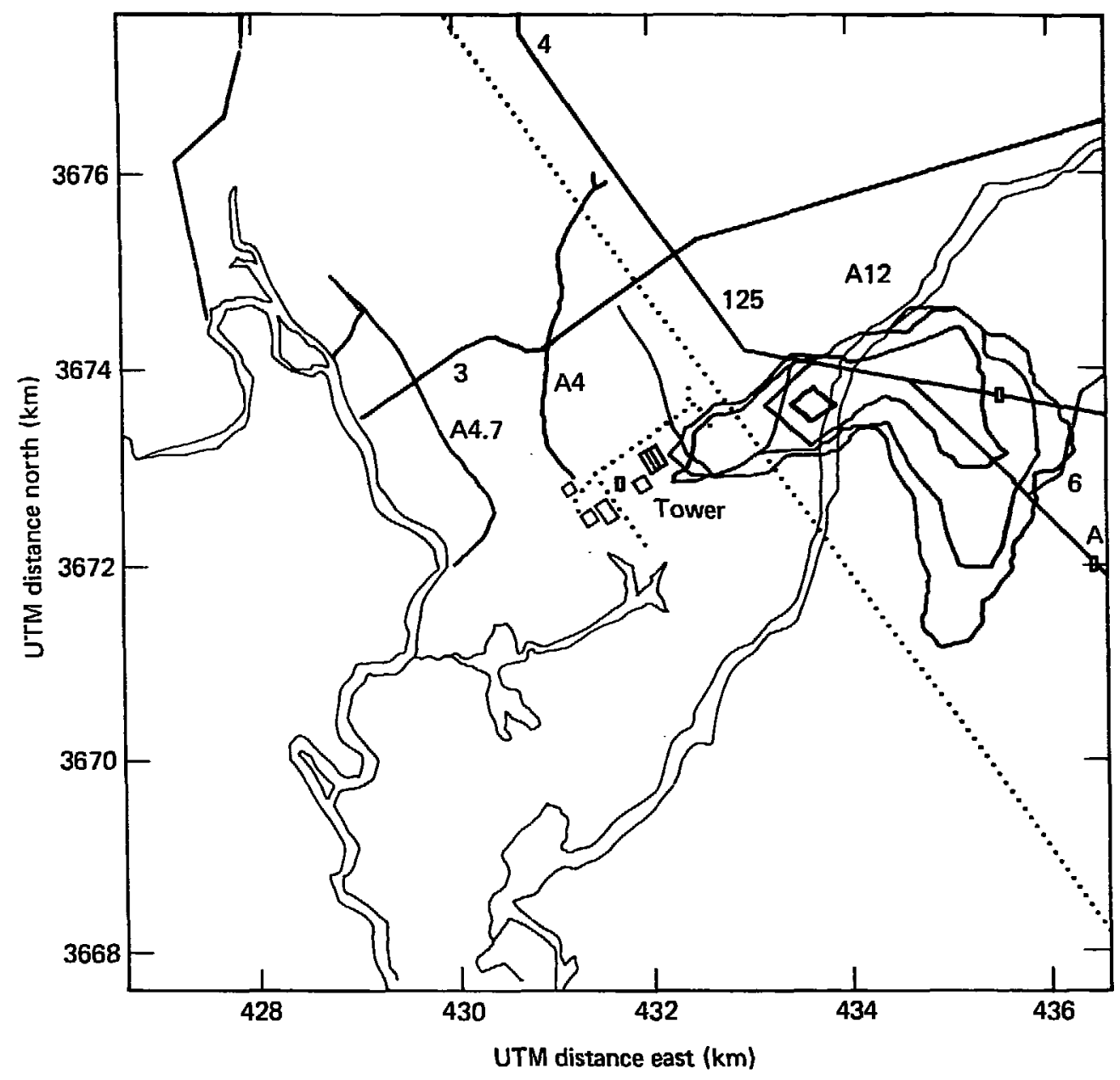

FIGURE Al. Depiction of isopleth pattern for instantaneous air concentration of hydrogen sulfide $\left(\mathrm{H}_{2} \mathrm{~S}\right)$ at two meters above ground level, as calculated for three hours after st; - nt of simulated continuous leak (initial time $1600 \mathrm{GMT}$, May 21, 1980; valid time $1900 \mathrm{GMT}$, May 21, 1980). Isopleths are $1000,100,10$ and $1 \mathrm{ppm}$, respectively.

The five remaining ARAC system alerts for accidents involving possible of $f$-site releases were minor in nature, but did exercise the system to various levels of response. Because two of the alerts - Prairie Island and Crystal River - were for commercial nuclear power stations previously unknown to the ARAC system, work was begun immediately to prepare the essential computer files. In both cases, NRC terminated ARAC involvement within two to three hours. The other three alerts involved two ineidents at LLNL and one at Rocky Flats Plant (RFP). The first LLNL event was our significant earthquake on January 24, 1980; our response 


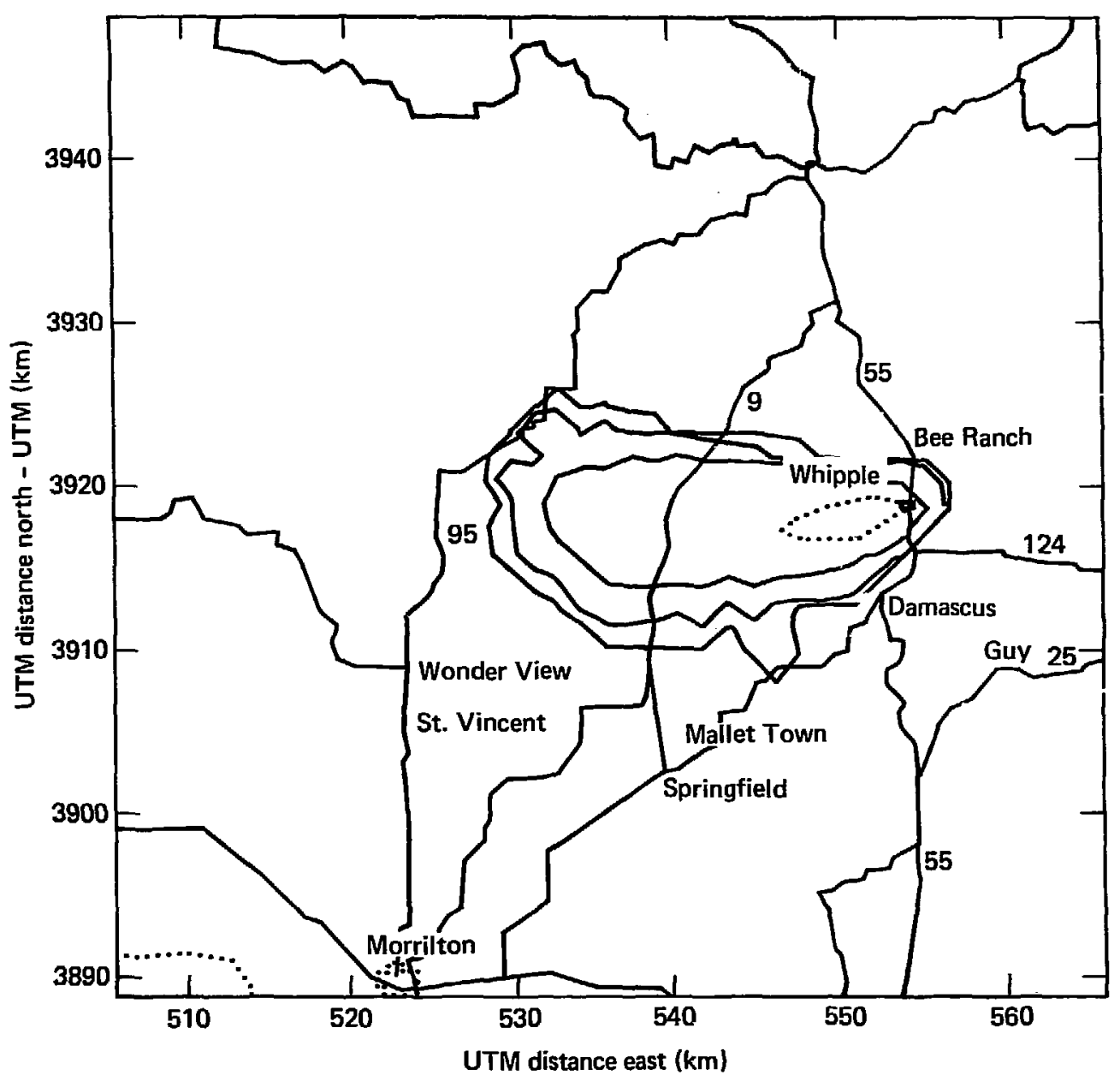

FIGURE A2. Depiction of normalized isopleth pattern for integrated inhalation dose of radioactive material at two meters above ground level three hours after simulated explosive dispersal accident at Titan II complex, Damascus, Arkansas. Isopleths are in millirem, ranging from $10^{-3}$ to $10^{-6}$, and must be multiplied by the number of kilograms to estimate the total dose.

consisted of preparing for calculations on spills, leaks, etc. that might have occurred. After about three hours, when it was determined that no calculations would be required, ARAC stood down. The second LLNL incident was a plutoniumhandling, glove-box accident on the night of April 17, 1980; ARAC involvement consisted of a callout and two-hour standby. On July 3,1980, we were put on alert for a radioactive-waste-incinerator filter fire at Rocky Flats. The situation was controlled quickly, and the alert was terminated within two hours. 


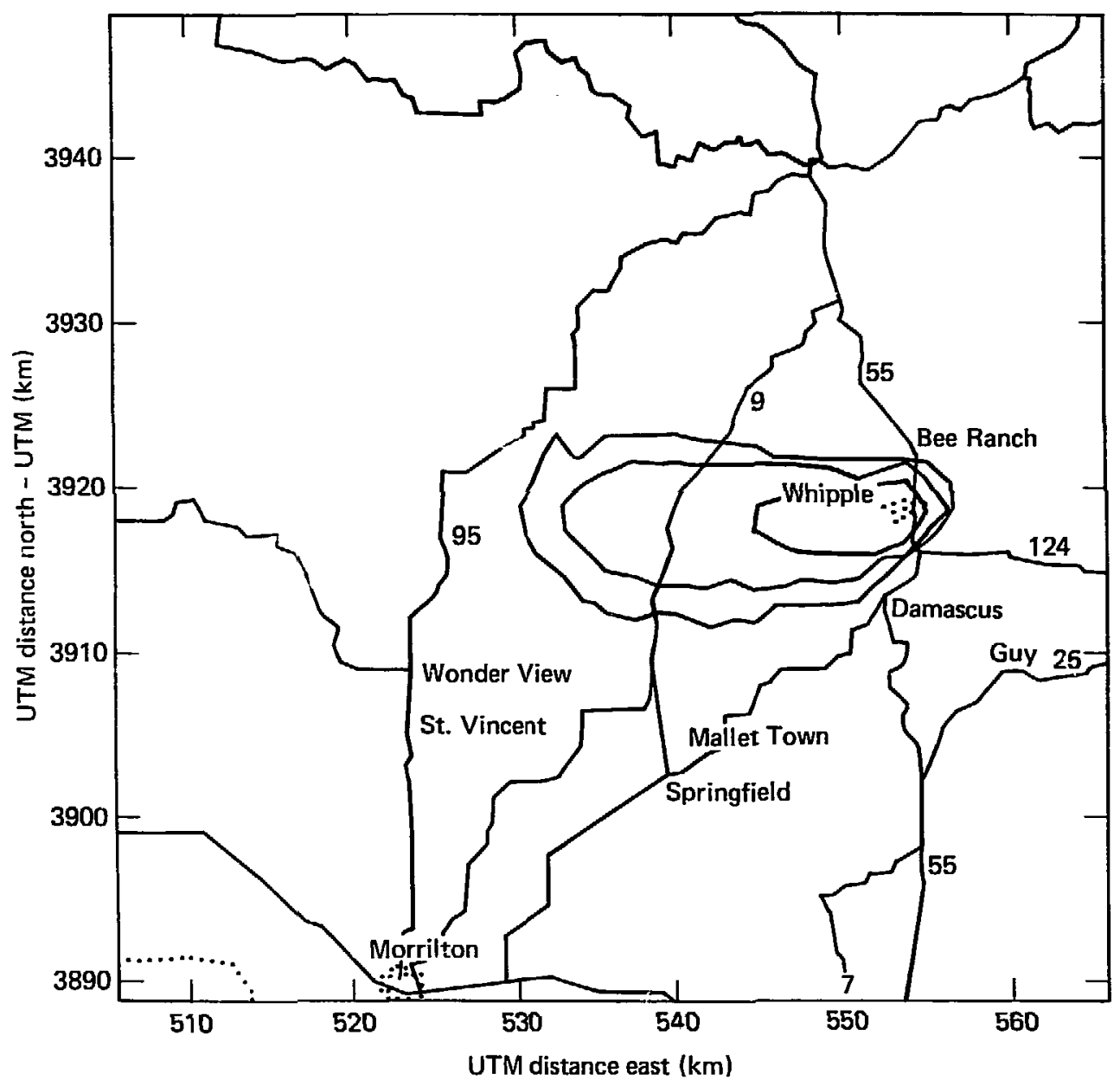

FIGURE A3. Depiction of normalized isopleth pattern for surface deposition of radioactive material three hours after simulated explosive dispersal accident. Isopleths are in micrograms per square meter, ranging from 30 to 0.03 , and must be multiplied by the number of kilograms to estimate total deposition.

\section{Exercises}

Four exercises were conducted during this year: two with fixed sites (LLNL and RFP), one involving DOD/U. S. Army personnel, and one with the NEST community: The fixed-site exercises, which lasted about six hours, involved many hours of model calculations and the interaction of six to eight staff members. The three-day DOD/U.S. Army exercise was a weapons aircraft-transport accident scenario; one staff member was deployed to the accident site, and three members 

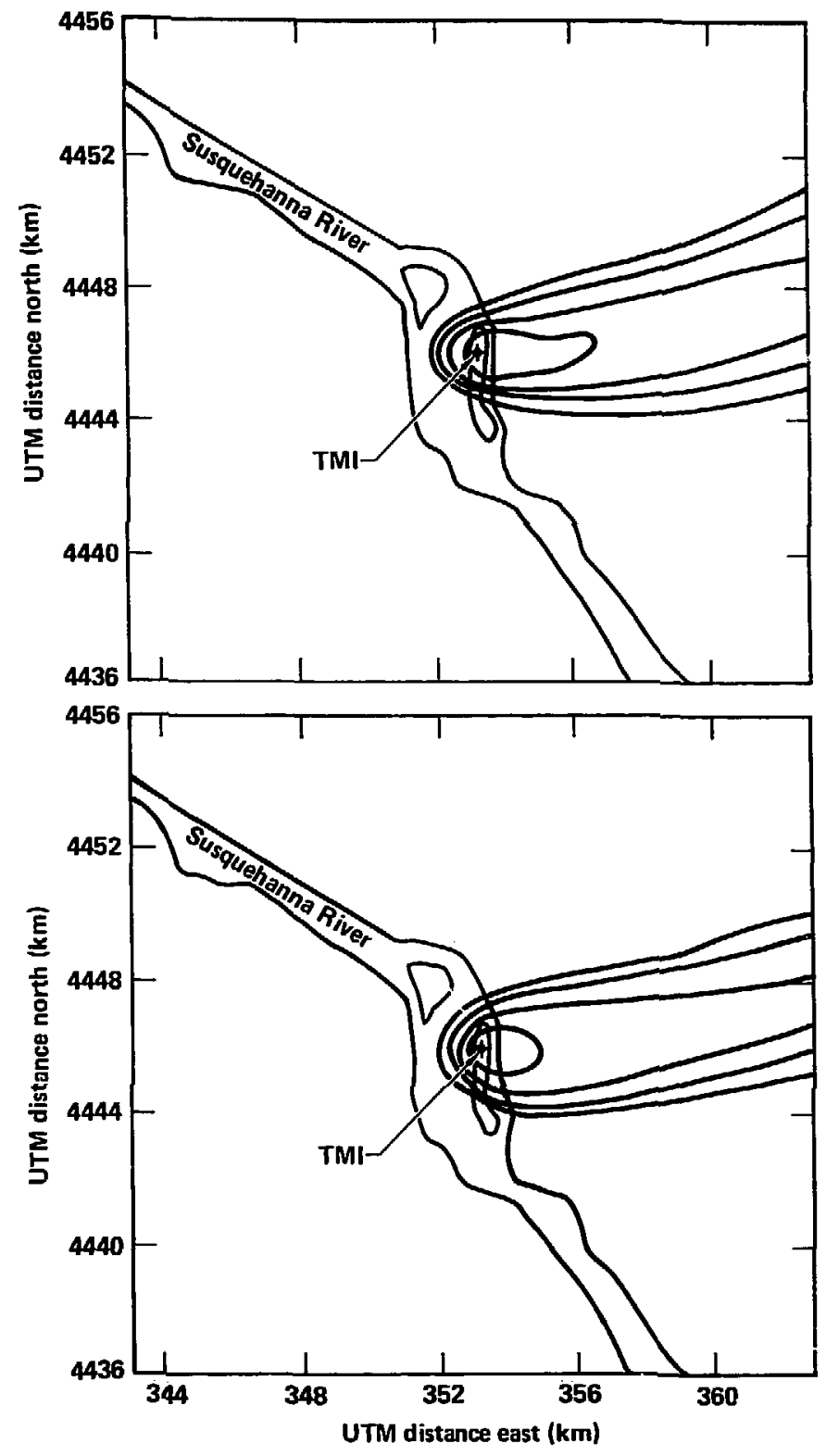

FIGURE A4. Depiction of normalized isopleth pattern for instantaneous air concentration at $60 \mathrm{~m}$ (top) and $2 \mathrm{~m}$ (bottom) above ground level, as calculated for a continuous release of ${ }^{85} \mathrm{Kr}$ from the TMl reactor. This depiction is valid for $0200 \mathrm{GMT}$, June 30,1980 , based on the 0100 GMT meteorological data. The isopleths are in units of $\mathrm{pCi} / \mathrm{m}^{3}$ and range from $1 \times 10^{-6}$ to $1 \times 10^{-9}$. 


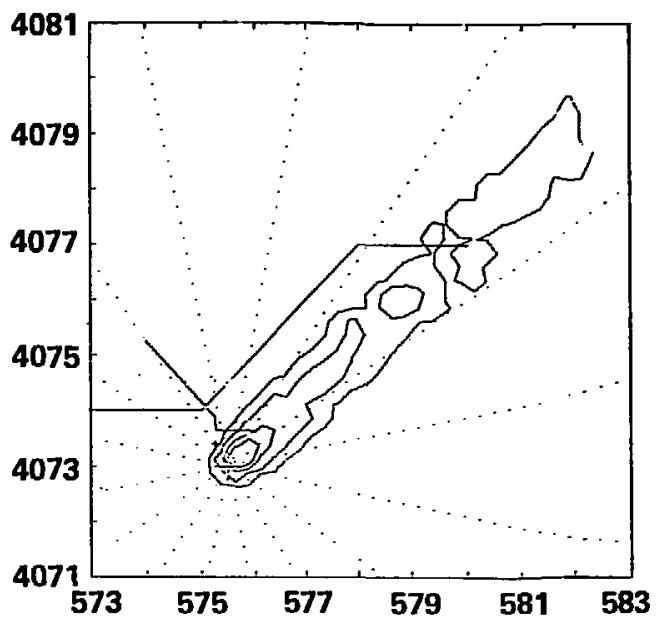

FIGURE A5. Fallout pattern from NUWAX-81, April 21, 1981, simulatea high-explosive detonation.

prepared occasional sample calculations. The NEST exercise a nuclear extortion scenario, simulated remote/independent operations, and involved little interaction with the ARAC center. Two staff members were deployed to the field for six days they operated essentially independently with precalculations and available resources.

\section{FY 1981}

During FY1981, ARAC responded to 8 alert notifications and 13 exercises that spanned periods of $2 \mathrm{~h}$ to 10 days. Table A2 lists the events in chronological order. Only December and May passed without significant ARAC involvement in some event.

Alerts

The People's Republic of China conducted an atmospheric nuclear device test on October 16,1980 , injecting a significant radioactive debris cloud into the upper troposphere and lower stratosphere. Calculations were prepared for the FAA twice daily for a period of several days. A nuclear extortion threat problem was handled on January 9-10, 1981. A full ARAC system response was initiated, ineluding the generation of a detailed topographic data base, meteorological data collection, initial Gaussian instantaneous-point-source (IPS) model calculations, and scheduling of personnel for off-hours/weekend work. The problem terminated uneventfully at midday on January 10.

On March 27, 1981, ARAC provided a complete system response to the Savannah River Plant (SRP) for a "near, though less than emergency" level release of tritium to the atmosphere. Calculations covering a period of six hours were prepared and delivered to the SRP/SRL staff for use in their offsite monitoring and assessment efforts. A full complement of ARAC staff members worked on the problem for five hours. 
TABLE A2. Summary of ARAC responses during FY1981.

\begin{tabular}{|c|c|c|c|c|}
\hline Date & $\begin{array}{l}\text { Type of } \\
\text { response }\end{array}$ & Location & Event & Duration \\
\hline $10 / 16 / 80$ & Alert & Northern Hemisphere & Chinese atmospheric nuclear test & $10 \mathrm{~d}$ \\
\hline $10 / 16 / 80$ & Alert & Sunol, California & Truck accident involving radioactive material & $3 \mathrm{~h}$ \\
\hline $11 / 20 / 80$ & Alert & Dothan, Alabama & $\begin{array}{l}\text { NRC/FEMA/DOE/State of Alabama exercise for } \\
\text { Farley i NPP }\end{array}$ & $5 \mathbf{h}$ \\
\hline $01 / 09 / 81$ & Alert & - & NEST response to extortion threat & $2 d$ \\
\hline $09 / 22 / 81$ & Alert & Shippingport, Pennsylvania & Beaver Valley NPP leak & $2.5 \mathrm{~h}$ \\
\hline $02 / 17 / 81$ & Exercise & $\begin{array}{l}\text { National Military Command } \\
\text { Center (NMCC) }\end{array}$ & DOD sommand post exercise & $2 \mathrm{~h}$ \\
\hline $02 / 24 / 81$ & Exercise & LLNL, Californie & LLN L/Livermore, county toxic gas exercise & $3 \mathrm{~h}$ \\
\hline $03 / 03 / 81$ & Exercise & Camp Roberts, California & Low-key NEST exercise & $3 d$ \\
\hline $03 / 04 / 81$ & Exercise & Oregon/Washington & NRC/DOE low-key exercise for Trojan NPP & $3 \mathrm{~h}$ \\
\hline $03 / 11 / 81$ & Alert & Delaware/New Jersey & Salem NPP leak & $2 \mathrm{~h}$ \\
\hline $03 / 27 / 81$ & Alert & $\begin{array}{l}\text { Savannah River Plant, } \\
\text { South Carolina }\end{array}$ & Tritium release & $5 \mathrm{~h}$ \\
\hline $04 / 09 / 81$ & Exercise & LLNL, Californis & LLNL evacuation exercise & $1 \mathrm{~h}$ \\
\hline $04 / 21 / 81$ & Exercise & Nevada Test Site & NUWAX-81 & $6 d$ \\
\hline $06 / 09 / 81$ & Alert & Baghdad, Irag & Reactor destruction & $2 d$ \\
\hline
\end{tabular}


TABLE A2. Continued.

\begin{tabular}{|c|c|c|c|c|}
\hline Date & $\begin{array}{l}\text { Type of } \\
\text { response }\end{array}$ & Location & Event & Duration \\
\hline $07 / 16 / 81$ & Alert & Dryton, Ohio & Mound Laboratory support request for toxic spill & $2 \mathrm{~h}$ \\
\hline $07 / 23 / 81$ & Exercise & INEL, Idaho & 24-h tracer study & $24 \mathrm{~h}$ \\
\hline $07 / 27 / 81$ & Exercise & INEL, Idaho & $24-h$ tracer study & $24 \mathrm{~h}$ \\
\hline $07 / 29 / 81$ & Exercise & Chicago, Illinois & $\begin{array}{l}\text { NRC/FEMA/DOE/State of nlinois/State of } \\
\text { Wisconsin exercise for Zion NPF }\end{array}$ & $6.5 \mathrm{~h}$ \\
\hline $08 / 05 / 81$ & Exercise & - & NEST field exercise & $5 \mathbf{d}$ \\
\hline $09 / 18 / 81$ & Exercise & Buchanan, New York & Indian Point NPP/State of New York exercise & $4 \mathrm{~h}$ \\
\hline $09 / 25 / 81$ & Exercise & Buchanan, New York & Indian Point NPP/State of New York exercise & $4 \mathrm{~h}$ \\
\hline
\end{tabular}


On July 16, 1981, Mound Laboratory called for assistance with transport and diffusion calculations for a non-DOE toxic chemical spill accident in downtown Dayton, Ohio. ARAC immediately acquired the meteorological data from nearby airports and commenced calculations. Since the source rate was unknown, normalized calculations were prepared. In less than two hours the problem was under control, and the emergency response was terminated.

A surface transport accident involving non-DOE owned nuclear material near Sunol, California, produced a "standby" alert on October 16, 1980, at the same time ARAC was assessing of the Chinese nuclear device test. No calculations were performed, and no release occurred.

On January 22, 1981, ARAC was put on alert for a possible emergency at the Beaver Valley Nuclear Power Plant (NPP) near Shippingport, Pennsylvania. This alert was terminated after $140 \mathrm{~min}$. Initial plant location and meteorological data acquisition had been accomplished, and terrain data generation was underway when the alert terminated.

An alert calling for possible emergency response was initiated March 11,1981 , for the Salem No. 1 NPP (New Jersey) pump-seal rupture and ensuing release. Site location and meteorological data coliection for the area were started. The emergency was terminated within two hours, and no model calculations were generated.

ARAC was put on alert for contingency calculations for the June 9, 1981, military bombing of the Iraqi reactor outside Baghdad. Initially, contingency caleulations were prepared for a single explosive puff/dispersal problem, followed by calculations for a continuous release. All meteorology was hypothetical because of the complete lack of Iraqi weather data (probably since the outbreak of the Iraq-Iran war). After a two-day alert, the problem reverted to a special assessment study for varius plausible and contingency situations.

Exercises

Of the 13 exercises involving ARAC participation listed in Table A2, the most significant are described below.

On April 9, 1981, ARAC participated in an LLNL evacuation exercise based on a toxic-substance transportation accident adjacent to the Laboratory. Prevailing meteorc 'ogy was used to make Gaussian model calcliations for the one-hour period.

ARAC participated fully in the large-scale NUWAX-81 exercise conducted by DOD/DOE at the Nevada Test Site during April 21-27, 1981. Approximately seven staff members were involved for five of the six days two meteorologist/assessment team members were deployed to the exereise site. Specialized data collection wes made throughout the period. Simple and complex model calculations were prepared for both radiological and chemical toxicity hazards. This exercise also provided an opportunity to test preliminary models designed to estimate particle resuspension and subsequent dispersal. The field team operated with a portable telecopier, a portable computer terminal, and DOE communications resources. Figure A6 shows a typical calculation for the exercise.

On July 29, 1981, a major NRC/FEMA/State of nllinois/State of Wisconsin exercise was conducted with the Commonwealth Edison Zion NPP. DOE was asked to demonstrate its capabilities and services. ARAC prepared several model calcula- 


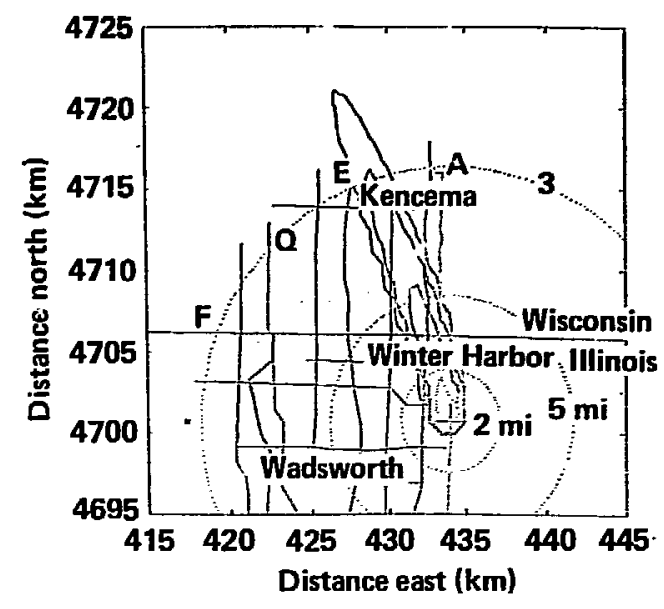

FIGURE A6. Depiction of simulated plume from the Zion nuclear power plant as calculated by ARAC during NRC/FEMA/State of nlinois/State of Wisconsin exercise.

tions that were used in the nearly day-long exercise. Figure A7 portrays the accident release plume as it extended from the power plant in lllinois across the border into Wisconsin.

In early August, a five-day DOE Nuclear Emergeney Search Team (NEST) exercise was conducted at a remote location. ARAC participation was extensive, involving specialized data collection, LLNL alert center support, model calculations, and specialized contingency assessments. One staff member was deployed to the exercise site with both a telecopier and a remote computer terminal.

\section{FY 1982}

During FY1982 ARAC responded to two emergencies, three alert notifications, and nine exercises. The longest, a NEST exercise, lasted nearly 12 hours. Table $A 3$ lists the events in chronological order. In addition, nine major assessments, exercise scenarios, and training courses were prepared utilizing the ARAC system.

\section{Emergencies}

The two "emergency" responses required this year were very different in nature and time span. The first emergency was a fire involving radioactive material at Rocky Flats. The fire was extinguished within seven minutes, no radioactive material was released, and the emergency was terminated after 45 min. Preliminary ARAC model calculations were furnished to the site. The second emergency was the rupture of a nuclear steam generator at the Robert Louis Ginna N uclear Power Plant outside of Rochester, New York. After subsequent releases of several reactor radionuclides, a "site area emergency" was declared. Since the Gina Plant was not a predefined ARAC site, all required information had to be assembled for the response. As a :esuIt of two new ARAC capabilities, final model calculations (including terrain effects) were delivered to $\mathrm{New}$ York State authorities within $2.5 \mathrm{~h}$ and overlaid on a local area map within $4 \mathrm{~h}$ (Fig. A7). New York State personnel provided some of the locat-area and plant-site meteorological data. The 


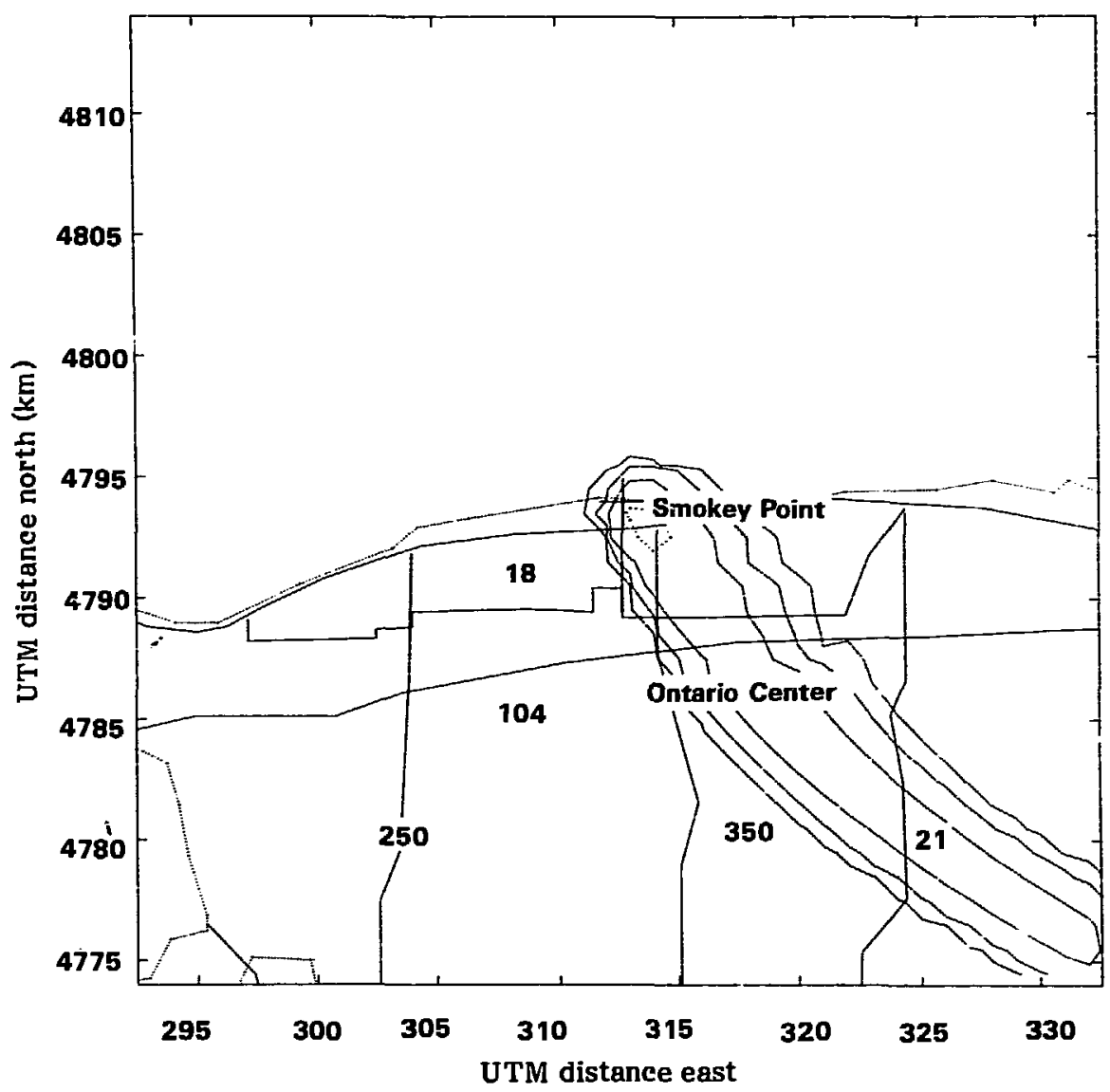

FIGURE A7. Depiction of normalized isopleth pattern of external whole body dose due to cloud exposure from a hypothetical ${ }^{133} \mathrm{Xe}$ release from the Ginna nuclear power plant. The isopleths range in value from $3 \times$ $10^{-4}$ to $3 \times 10^{-7} \mathrm{mrem}$.

response was terminated after five hours when the site area emergency was cancelled.

Alerts

None the three "alert" responses called for model calculations. Two sites Holbrook Arizona, and Franeis E. Warren AFB, near Cheyenne, Wyoming - were not defined ARAC sites. Had an actual release oceured, such as that for the Ginna power plant response, a substantial ef fort would have been required.

\section{Exercises}

The nine live exercises and nine major assessment/scenario calculations that utilized the ARAC system the most this year have served as continuing training and evaluation opportunities for both the ARAC staff and system. 
TABLE A3. Summary of ARAC responses during FY 1982.

\begin{tabular}{|c|c|c|c|c|}
\hline Date & $\begin{array}{l}\text { Type of } \\
\text { response }\end{array}$ & Location & Event & Duration (h) \\
\hline $11 / 04 / 81$ & Emergency & Rocky Flats Plant, Colorado & Fire involving uranium & 0.75 \\
\hline $11 / 24 / 81$ & Exercise & $\begin{array}{l}\text { Sacramento and Rancho Seco } \\
\text { N PP, California }\end{array}$ & Planned joint exercise for FEMA & 3.5 \\
\hline $12 / 04 / 81$ & Exercise & $\begin{array}{l}\text { Sacramento and Rancho Seco } \\
\text { NPP, California }\end{array}$ & Planned joint exercise for FEMA & 4.0 \\
\hline $12 / 08 / 81$ & Exercise & Rocky Flats Plant, Colorado & Planned exercise with state & 3.5 \\
\hline $01 / 16 / 82$ & Alert & Holbrook, Arizona & $\begin{array}{l}\text { Possible tritium release from } \\
\text { cargo in a truck accident }\end{array}$ & 2.5 \\
\hline $01 / 19 / 82$ & Exercise & $\begin{array}{l}\text { Sacramento and Rancho Seco } \\
\text { NPP, California }\end{array}$ & Planned joint exercise for FEMA & 3.0 \\
\hline $01 / 25 / 82$ & Emergency & Rochester, New York & $\begin{array}{l}\text { R. L. Ginna N PP ruptured nuclear } \\
\text { steam generator }\end{array}$ & 5.0 \\
\hline $01 / 26 / 82$ & Exercise & McGuire AFB, New Jersey & $\begin{array}{l}\text { Planned exercise with } 2 \text { lst Air } \\
\text { Force }\end{array}$ & \\
\hline $02 / 19 / 82$ & Alert & Middletown, Pennsylvania & $\begin{array}{l}\text { Three Mile Island N PP-2 possible } \\
\text { hydrogen gas problem }\end{array}$ & 2.5 \\
\hline $03 / 03 / 82$ & Exercise & Albany and Buchanan, New York & $\begin{array}{l}\text { Indian Point NPP planned exercise } \\
\text { for state }\end{array}$ & 3.5 \\
\hline $03 / 18 / 82$ & Exercise & $\begin{array}{l}\text { LLNL, Site } 300, \text { Livermore, } \\
\text { California }\end{array}$ & No-notice NEST exercise & 12.0 \\
\hline $05 / 04 / 82$ & Exercise & U.S. Navy facility & Planned exercise & 2.0 \\
\hline $05 / 28 / 82$ & Alert & $\begin{array}{l}\text { Franeis E. Warren AFB, } \\
\text { Wyoming }\end{array}$ & Potential toxic chemical spill & 1.0 \\
\hline $08 / 17 / 82$ & Exercise & Rocky Flats Plant, Colorado & Planned exercise & 6.0 \\
\hline
\end{tabular}

